\title{
CONSTITUTIONALITY OF MANDATORY RELIGIOUS REQUIREMENTS IN CHILD CARE
}

WHEN parents are unfit, unwilling, or tunable to care for their children, the state intervenes to protect the child's welfare. ${ }^{1}$ 'The prime consideration for state action is the child's best interests. ${ }^{2}$ However, since parental rights are not easily severed, ${ }^{3}$ there must be a clear showing of parental inadequacy before a court will substitute its judgment of the child's needs for that of his parents. ${ }^{4}$ One of the most vital parental prerogatives is the right to control the child's religious training.5 Statutes, case law and administrative regulations demonstrate the concern of legislatures, courts, and clepartments of welfare in preserving the religious faith of children who must be placed away from their parents. ${ }^{6}$ The degree to which religious considerations are part of or prevail over considerations of the child's best interests varies among the states and results in diverse effects on the administration of child welfare programs.

\section{Existing Rules}

Three approaches to the importance of religion in child placement are exemplified in present practice. ${ }^{\top}$ Some jurisdictions adopt the equity rule that,

1. Purinton v. Jamrock, 195 Mass. 187, 201, 80 N.E. 802, 805 (1907); In rc Sharp, 15 Idaho 120, 96 Pac. 563 (1908). See Mack, The Juvenile Court, 23 HAkv. L. Ruv. 104 (1909).

2. Ex parte Badger, 286 Mo. 139, 226 S.W. 936 (1920); Commonwealth c.r rcl. v. Daven, $268 \mathrm{~Pa}$. 416, 148 Atl. 524 (1930); Morris v. Jackson, 66 Wyo. 369, 212 P.2d 78 (1949); PoMeroy, EQuity Jurisdiction $\& 1307$ (5th ed. 1941); Madden, DoMestic RELATIONS §§ 107-09 (1931).

3. Hernandez v. Thomas, 50 Fla. 522 (1905). The rights of fit parents cannot be severed without their consent.

4. E.g., People ex rel. Portnoy v. Strasser, 303 N.Y. 539, 104 N.E.2d 805 (1952).

5. Prince v. Massachusetts, 321 U.S. 158, 165-66 (1944) (dictum).

6. For a comprehensive collection and a detailed analysis of the cases and statutes dealing with religion and child placement, see Note, Religion as a Factor in Adoption, Guardianship and Custody, 54 CoLvm. L. Rev. 376 (1954). Administrative regulations are set out in note 12 infra and accompanying text. The cases deal with the separate problems of adoption, guardianship, and custody, but are used interchangably as precedent and involve the same legal considerations in so far as the instant problem is concerncd.

7. Case law within as well as among the states is inconsistent. Thus, precedent for more than one rule may exist within a state. Compare Matter of Santos, 278 App. Div. 373, 105 N.Y.S.2d 716 (1st Dep't 1951), appeal dismissed on other grounds, 304 N.Y. 483, 109 N.E.2d 71 (1952), where the court ordered two children, who had been well-placed, removed from a home of a different religion, with In re Krenkel, 278 App. Div. 573, 102 N.Y.S.2d 456 (2nd Dep't 1951), where an adoption of an illegitimate child across religious lines was affirmed without opinion despite the natural parents' marriage and the withdrawal of the mother's consent. See Pfeffer, Church, State awd Frfedom 649 n.30 (1953). Decisions within the same court sometimes conflict. Comparc Matter of Vardinakis, 160 Misc. 13, 289 N.Y. Supp. 355 (N.Y. Dom. Rel. Ct. 1936), where the child's best interests determined custody, with Ramon v. Ramon, 34 N.Y.S.2d 100 (N.Y. 
since the child's best interests must govern, religion is only one of many factors for consideration. 8 In other jurisdictions religious considerations prevail unless the child's welfare clearly demands care which is unavailable from custodians of the same religion. ${ }^{9}$ These approaches differ in degree; neither permits religion to become an absolutely controlling factor. On the other hand, a third rule completely eliminates judicial and administrative discretion: custodians and probation officers are required to be of the same religion as the child's parents regardless of other compelling circumstances. ${ }^{10}$

Dom. Rel. Ct. 1942), where religious considerations played a dominant role. Compor: also In re Riley, $20 \mathrm{~Pa}$. Dist. 745 (1911), with Commonwealth ex rel. Burke v. Birch, 169 $\mathrm{Pa}$. Super. 537, 83 A.2d 426 (1951). Courts of some states have not yet passed on the issue.

8. Courts of equity have inherent jurisdiction over the custody of children. For the development of this jurisdiction, see STORY, EQUTTY JuRISPRUdesce $\$ \S 1743-52$ (14th ed. 1918). The chancellor exercised wide powers of discretion in determining custody solely on the basis of the child's best interests. Finlay v. Finlay, 240 N.Y. 429, 14S N.E. 624 (1925).

Several jurisdictions have adopted this equity approach. Whalen $v$. Olmstead, 61 Conn. 263, 23 Atl. 964 (1891) ; In re Guardianship of Waite, 190 Iowa 182, 180 N.W. 159 (1920); Denton v. James, 107 Kan. 729, 193 Pac. 307 (1920); In re MIcKenzie, 197 Minn. 234, 266 N.W. 746 (1936) ; Commonwealth $e x$ rel. Donie v. Ferree, 175 Pa. Super. 586, 106 A.2d 681 (1954). In addition, some courts have held statutes requiring children to be placed with persons of the same religion "whenever practicable" to be merely advisory. Guardianship of Walsh, 100 Cal. App. 2d 194, 223 P.2d 322 (1950); People ex rel. v. Bolton, 27 Colo. App. 39, 146 Pac. $4 S 9$ (1915); State ex rcl. Balker v. Bird, 253 11o. 569, 162 S.W. 119 (1913); Butcher's Estate, 266 Pa. 479, 109 Atl. CS3 (1920).

9. Some courts have interpreted statutes which require custodians to be of the same religion as the child "whenever practicable" as limiting the court's discretion, but not eliminating it. In approving an adoption across religious lines, one court said, "whereas befure the new statute there was no definite rule binding upon the judge in any sct of circumstances as to how much weight was to be given to any one of the several elements as against the others, he is now bound to give controlling effect to identity of religious faith when practicable but not otherwise." Petition of Gally, 329 Mass. 143, 107 N.E.2d 21, 25 (1951). See also State ex rel. Evangelical Lutheran Kinderfreund Society v. White, 123 IFinn. 50S, 144 N.W. 157 (1913). Cases often allow placement across religious lines with the proviso that the child must be educated in the parents religion. Miatter of Mancini, 89 Misc. S3, 151 N.Y. Supp. 387 (Surr. Ct. 1915) ; Miatter of Korte, 78 Mise. 276, 139 N.Y. Supp. 444 (County Ct. 1912) ; cf. Commonwealth ex rel. Stack v. Stack, 141 P2 Super. 147, 15 A.2d 76 (1940).

10. Several states have equated the best interests of its children with religious considerations. Two states have enacted mandatory statutes which prohibit placement with custodians of a different religion. N.D. REv. CoDE $\$ 27-1622$ (1943) ; R.I. GE:. LAws c. 616, § 12 (1938), R.I. LAws 1946 c. 1772, § 26 . And DEL. Cope Axs. tit. 13, §911 (1953), requires at least one adoptive parent to be of the same religion unless the parents stipulate either a different religion or their indifference. While no court has yet interpreted the statute, it might be held impossible to arrange an adoption across religious lines if both parents are dead. Maine has an involved placement requirement. MIs Rav. Sr.s. c. 25, $\$ 252$ (1954). Children must be placed in homes of the same religion. If such a home is unavailable, they must be placed in an institution governed by persons of the same religion. If no such institution is available, the child is to be placed in a suitable home or institution until one of the same religion can be found.

A mandatory requirement was created from a "when practicable" statute in Mlatter of 
Treatment of religion as a determinative factor in child placement is more prevalent than is commonly assumed. ${ }^{11}$ While mandatory requirements appear in the statutes or case law of only a few states, administrative regulations or practices in others often apply discretionary statutory language in a similarly rigid manner. ${ }^{12}$ These actions are rarely exposed to judicial review, ${ }^{13}$ but their

Santos, 278 App. Div. 373, 105 N.Y.S.2d 716 (1st Dep't 1951), appeal dismissed on other grounds, 304 N.Y. 483, 109 N.E.2d 71 (1952). In that case, two children were entrusted to Jewish care by their Catholic mother. Four years later the mother sought to regain custody from prospective adoptive parents. The Appellate Division reversed the trial court's findings that it was for the best interests of the children to remain in the adoptive home, and ordered the children removed to a Catholic institution. "When practicable" was interpreted to mean "when available," leaving no discretion in the court as long as room could be found for the children in an institution of the same faith. The weakness of this rationale is demonstrated by respondent's complete failure to raise this argument before the court of appeals. See Brief for Respondent, Matter of Santos, 304 N.Y. 483, 109 N.E.21 71 (1952). Cf. Petition of Gally, supra note 9. But see Petitions of Goldman, 121 N.E.2d 843 (Mlass. 1954), cert. denied, 23 U.S.L. WEEk 3201 (U.S. 1955), (which is in accord with Santos. The Santos case was critically discussed in Note, 65 HARv. L. REv. 694 (1952), and in Pfeffer, Church, State and Freedom 588-91 (1953).

A recent investigation of adoption practices in New York City indicates this statute is so rigorously applied that the phrase "when practicable" is disregarded. GellnokN, Children and Families in the Courts of New York City 263-65 (1954). But si" Letter from Shad Polier, Counsel, Louise Wise Services, N.Y., to Yalc Laze Journal, April 8, 1955, on file in Yale Law Library: "[D]uring the past thirty ycars [almost all] Surrogates ... have permitted adoptions across religious lines upon proof . . . that this is in accordance with the natural mother's wishes and . . not in a single instance . . . has a Surrogate refused an adoption on such ground." And see In re Krenkel, 278 App. 1Div. 574, 102 N.Y.S.2d 456 (2d Dep't 1951), discussed in PfefFer, Church, STate and Finerdom 649 n.30 (1953).

11. Information was solicited from seventeen children's courts and from the Depart ments of Welfare of every state. Thirty four states and eight courts responded and many forwarded administrative regulations dealing with child welfare programs. Private child welfare agencies, civic organizations concerned with child welfare, social workers, probation officers, and children's court judges were also consulted by letter and interview (hereinafter cited as INTERvIEws). This material supplied much of the information relied on in the subsequent portions of this note and is on file at the Yale Law Library.

12. For examples of administrative regulations: In Missouri, "a child must be placed in a home of like religious faith ...." Mo. Dep't of Welfare, Foster Hone Cake, Child Welfare Manual 14. Cf. Mo. Ann. Stat. $\$ \$ 210.160,211.140,211.390$ (Vernon 1949). An administrative inconsistency seems to exist, however, since the State Child Welfare Supervisor feels that emotional well-being and the potential for satisfactory parenthood are more essential for foster parents than educational and cultural background, and that mandatory criteria for placement "would seem very unwise." Letter from Miss Lorena Scherer, State Child Welfare Supervisor, Missouri, Feb. 24, 1954.

The New York administrative regulations are not uniform. A mandatory requirement is imposed on placement in foster homes, N.Y. Dep't of Soctal Welfare, Sochal Welfare: MaNUal pt. III, p. 27 (1952), while the "when practicable" requirements of the statute are spelled out regarding adoption, $i d$. at 58, and children's institutions, N.Y. Der'r or Social Welfare, Ains and Practices for Children's Institutions 23 (1951).

In New Jersey, "[the public] agency is bound by law to place a child in a home of the same religion as its parents, and the private agencies, although not so refuircd, usually do." Letter from J. E. Alloway, Executive Director, Board of Child Welfare, 
importance in the field of child placement becomes evident as an increasing number of children are handled by such agencies. ${ }^{14}$

N.J., June 24, 1954. A similar requirement is set out in State Bosmo of Chmo Wesfarse, A Hone Shourd Provtee 6 (1950). Cf. N.J. Stat. ANx. \$ 30:4C-26 (Supp. 1954). New Jersey is the only state which requires references from a clergyman before a couple can petition for adoption. Letter from J. E. Alloway supro. The Minumus Stavipanes of Approved Adortion Practice, promulgated by the Board of Child Weliare as a guide to private agencies, recites a "whenever possible" requirement.

For examples of administrative practice: In Maryland, "the law requires that children be placed in foster homes or institutions of the same religious faith as their families and that requirement is carried out in selecting the placement plan for the child .... The standards set for selection of foster and adoption homes are by administrative regulation, except the legal requirement that children be placed in homes of the same religivus faith as the homes from which they came." Letter from Thomas J.S. Waxter, Director, State Department of Public Welfare, Maryiand, March 5, 1954. Cf. Mp. Axx. Cone Gex. Laws art. 88A, § 26 (1951).

In Arkansas, "unless there is a special request, there is nu restriction as to foster parents of the same religion but, in adoption, children are placed only in homes falling into the same main religious group ...." Letter from Miss Ruth Johnston, Director of Child Welfare, Arkansas, March 3, 1954. Cf. ARx. Stat. Axx. \$ $45-229$ (1948).

In Colorado, "children are always placed in homes of their own religious faith." Letter from Marie C. Smith, Director, Child Welfare Division, Department of Public Welfare, Colorado, April 13, 1954. Cf. Cozo. Rev. Sr.tr. Axx. c. 22, art. 1, $\S 7(3)$ (1953).

For examples of inflexible but not mandatory requirements: California will only alluw placements across religious lines with parental consent. Letter from C.I. Schattland, Director, Department of Social Welfare, California, March 5, 1954; Dep'T os Soctik Welfare, Stattardos for Child Placting Agenctes in Califormia 8 (1947). (f. Cal Wel. \& Insts. Cone $\$ \S 551,552$ (1952). The Court of Common Pleas, Division of Domestic Relations, Lucas County, Ohio, follows a similar procedure. Letter from Paul W. Alexander, Judge, Court of Common Pleas, Division of Domestic Relations, Lueas County, Ohio, March 6, 1954. Cf. OHro Kev. Cone ANx. \$2151.32 (1954). In the absence of any statute, Texas applies the same rule, Texas State Dep't of Punuc Werfare, Manual of Services \$ 2362.14(1) (1952), and the Juvenile Court, Dade County, Florida generally insists on preserving religious identity. Letter from Walter H. Bechham, Judge, Juvenile and Domestic Relations Court, Dade County, Florida, Feb. 26, 1954.

13. Research has disclosed no case in which an administrative regulation in this field was challenged. The primary reason for this is that most of the cases deal with placemunt so that the children involved are almost always dependent, neglected, or delinquent and come from low income families who lack both the awareness and the muans to cumplain of the regulations and procedures. See Polmer, Everrose's Cumbrex, Norony's CunL. 92-98 (1941) ; Mack, The Jat'enile Court, 23 Hanv. L. REv. 104, 116 (1909). Children's court procedure is under the almost absolute control of the individual judge. Few persuns before the court have legal advice. And, since the pruceedings are contidential, few parents would like to subject their child to the notoriety of an appeal. Thus, abuses can and do occur. See id. at 11S-19, quoting from Mill v. Brown, 31 Ctah 473, 83 Pac. 609 (1907). See also KaHa, A Court For Chilnsex 98-123, 268-70 (1953); Gruluuss, op. cit. supra note 10, at $\$ 1-\$ 5$. These two books were sponsored by the Citizens' Cummittee on Children of New York City and the Bar of the City of New Yurk respectively, and are excellent studies of New York City's children's courts.

14. Twenty three states reported an increase in the number of children given service either for adoption or placement. Seven could not furnish statistics and fus rugorted the number of children handled had remained constant over the past several years. See Arnold, Meeting the Needs of Childen and Youth, 25 Soc. Serv. Rev. 156 (1951). 


\section{Effect of Religious Requirements on Child Welfare}

Stringent religious requirements have several adverse effects on child welfare programs. By unduly restricting discretion, they limit the utilization of modern techniques for providing child care and preclude the effective use of available facilities. Furthermore, they restrict the choice and hamper the efficiency of probation officers. And when imposed as a condition of probation, they play a doubtful or negative role in the rehabilitation of neglected and delinquent children.

Effect on use of scientific techniques. Psychological and sociological techniques are relied upon in most states to implement provisions for child welfare. ${ }^{16}$ These techniques operate on the premise that children's needs are determined by many interrelated factors. ${ }^{16}$ Since these factors vary from case to case, no hard and fast rules can prove effective in all situations. ${ }^{17}$ Older children generally respond to institutional care while children under six years of age require a home environment. ${ }^{18}$ Normal children can be cared for fairly easily;

15. Twenty three states submitted their regulations setting up minimum standards for child placement and child caring agencies. All required such agencies to maintain traincd staffs to conduct social studies of every child in order to determine his needs, and child placement agencies are required to investigate prospective homes in the same way. Most of these states follow the recommendations in Child Welfare Lengue of AMrrich, Standards of Foster Care for Children in Institutions and Standards for Cuildren's Organizations Providing Foster Family Care. See aiso Lerner, Diagnostic Basis of Institutional Care for Children, 33 Soc. CASEwork 105 (1952); Lenroot, Child Welfare-A Challenge to Both Private and Public Agencies, 24 Soc. Serv. Rev., 1, 4 (1950).

Most statutes creating specialized children's courts provide either for a psychintric bureau as part of the court staff, e.g., N.Y. DoM. REL. CT. ACT $\$ 33$, or authorize the court to order psychiatric examinations when necessary, Mp. ANN. CodE GEN. LAws art. $26, \S 62$ (1951). Children's courts also have a trained staff of probation officers or access thereto.

Social studies also play an important part in adoptions. An investigation of the suitability of the child for placement in the adoptive home is a prerequisite for any adoption petition. The state departments of welfare are usually responsible for conducting such investigations, but often accept those already performed by competent private agencies. For the adverse effect of too strict religious requirements on investigations, see Krakow v. Department of Public Welfare, 326 Mass. 452, 95 N.E.2d 184 (1950).

16. The factors set out in this paragraph of the text were compiled from the literature supplied by twenty four states. The other states included no information on the subject. All criteria are administrative and the result of experience in the field of child care, except religion which is made mandatory by law in some states and by regulation in others. Sce notes 10 and 11 supra.

17. "There are no concrete criteria for determining what type of home will best serve the needs of a particular child . . . that can be written down objectively and applied like a ruler." Letter from Miss Esther L. Immer, Supervisor of Special Studies, Department of Social Welfare, Iowa, April 12, 1954. Twenty other states indicated that cach child presented an individual case which could only be handled by individual consideration.

18. "With one or two exceptions, institutions are not used for infants or pre-school children. Adolescent children are more likely to need and accept group homes." Letter from Fred DelliQuardi, Director, Division for Children and Youth, State Department of 
the physically or emotionally handicapped require specialized treatment. All prospective custodians should meet general standards of financial security, emotional stability, and appropriate motivation. But intellectual capacity of both parent and child, ability of the former to develop special aptitudes, and a racial, cultural, and religious background to which the individual child can readily adjust require particular attention in each case.

Mandatory religious requirements ignore the basic premise that each placement problem is unique. ${ }^{19}$ This is most clearly illustrated in the extreme cases where, despite the traumatic effect of disrupting a satisfactory adjustment, children have been withdrawn from the homes of custodians having a different religion. ${ }^{20}$ But in any placement situation a requirement which subordinates all other considerations precludes a determination of the best interest of the child. ${ }^{21}$ Religion should be treated as any other factor entering into decisions

Public Welfare, Wisconsin, March 30, 1954. "No child under six is recommended for institutional care by this agency." Miss Ruth Johnston, Director of Child Welfare, Arkansas, March 3, 1954. Twenty six states follow this practice.

19. "The weight given to these various factors is a matter of discretion with the judge. ... The application of all these criteria in an individual situation is a matter of judgment, training and experience." Letter from Miss Ruth Bowen, Supervisor, Children's Division, Department of Social Welfare, Michigan, March 12, 1954. "In regard to the relative weight of these criteria, this has not been given consideration since the factors above are considered in relation to what is best for the child, and since degrce of capacity as parents may differ in certain instances it does not seem possible that we could structuralize these criteria in such a way as to assign specific weights to them. The main question is . . What is best for the child? . . ." Letter from Joseph H. Roe, Director, Division of Child Welfare Services, Montana, Míarch 2, 1954. Similar statements were received from seven other states. No specific importance was attached to any one criterion except in those states with mandatory religious requirements. See notes 10 and 12 supro.

20. See Matter of Santos, 278 App. Div. 373, 105 N.Y.S.2d 716 (1st Dep't 1951), appeal dismissed on other grounds, 304 N.Y. 483, 109 N.E.2d 71 (1952), where the' appellate court ordered the removal of two children from a Jewish adoptive home to a Catholie agency despite the trial court's findings that the evidence "clearly portrays the happiness of the children, their sense of being Jewish, and the unusually fine opportunity now upen to them." Transcript of Record, p. 682, Mfatter of Santos, 304 N.Y. 483 (1952). The trial court had concluded that these "children are now, in thought, associatiun, and conduct, Jewesses, and a forced change to another environment and instructions in a different religious faith would be a tragic disregard of their welfare." Id. at 695.

A New York statute provides for the revocation of prior commitment orders if the child's religion was erroneously reported in the prior hearings. N.Y. Dass. REL. $C_{T}$. AtT $\$ 86(3)$. Since a large number of adoptions are privately arranged withaut extensive investigation of either the child's background or his suitability to the adoptive hume, the child's religion could be erroneously reported, either by mistake or design. Comment, Ifoppets on the 1larket, 59 YaLE L.J. 715 (1950). Thus, this provision may be invulsed to upset such adoptions after the child has made a satisfactory adjustment to the home.

21. "A mandatory provision that placement must be with the same religious faith as the parents would seem most undesirable. It has been our experience in the ficld of laws relating to child protection that flexibility and discretion is always preferable to mandatory requirements. It would also seem a mere matter of common sense that the harmony of personalities between adoptive or foster parents and the child involved would be a far more important factor than the matter of religious faith." Letter from Brooke Wunniclse, 
on child placement. ${ }^{22}$ Its importance should depend on the education, interests, and emotional needs of the individual as well as the choice of available custodians. $^{23}$ Where persons of the same religion are as capable of caring for the child as those of a different religion, the child should be placed with his coreligionists. ${ }^{24}$ But where persons of a different religion can provide better care, the court or agency should be able to place across religious lines. ${ }^{25}$ Effect on use of existing facilities. Facilities for both long and short term child care are grossly inadequate. ${ }^{26}$ Private homes meeting requisite psychological,

Executive Secretary, Wyoming Youth Council, March 4, 1954. "It would seem very uInwise to set up a mandatory criteria [sic] for placement. The field of social work hats developed a body of knowledge as background for an application by the skilled practitioner in meeting individual children's needs." Letter from Miss Lorena Scherer, State Child Welfare Supervisor, Missouri, Feb. 24, 1954.

22. The standard adoption law suggested by the Children's Bureau contains no religious requirements, but recommends that the child's religious heritage should be included in the social study and report to the court. Federal Securutr Agency Children's Bureau, Essentials of Adoption Law and Procedure 17 (1949). A "when practicable" requirement is in the Standard Juvenile Court Act drafted by the National Probation and Parole Association, but there is no indication that it is to be applied inflexibly. NATIoNAL Probation and Parole Ass'n, A Standard Juvenile Court Act (1949).

23. "The primary factor in determining the type of home selected for a particular child is drawn from the background of the child itself. The intent is to place the child in a home which would be as near a normal situation as possible. We would then try to select adoptive parents who had the same racial, religious and cultural backgroundparents who would have roughly the same mental ability as the child." Letter from John F. Larson, Director, Bureau of Services for Children, Utah, March 9, 1954.

24. All states which provided information, agreed on this procedure.

25. See Commonwealth $e x$ rel. Kuntz v. Stackhouse, 176 Pa. Super. 361, 108 A.2d 73 (1954), cert. denied, 23 U.S.L. WEEK 3242 (U.S. 1955). "The few times in which I believe this discretionary power [to place across religious lines] should be exercised is when adoption agencies have made a long, conscientiaus search for adoptive parents of the same religion as the child. If the search has been fruitless and therefore the child could not know the security and feel the sense of belonging which adoptive parents could give him, then I believe that the child should be given that opportunity through placement with a couple of another faith rather than face long-time boarding care in a foster care agency under the auspices of his religious faith." Letter from Dorothea Coe, Executive Director, The Spence-Chapin Adoption Service, New York, March 5, 1954. The result feared in the above quotation is what occurred as an aftermath of the Santos case. The children remained in an institution for a long period of time after the case. INTERvIEws.

Religious differences should not preclude adoption of children who are physically or emotionally handicapped and difficult to place. For other compelling reasons to place across religious lines, see the next section of text dealing with the shortage of facilities for child care. For a general discussion of religious factors and adoption, see Note, Riligious Factors in Adoption, 28 IND. L.J. 401 (1953).

26. "For those children who must be cared for away from their own homes, facilities are far from adequate. Nowhere in the country are there enough foster-family homes or specialized group-care facilities to meet the need. Outside metropolitan areas the lack is even more acute." Arnold, Meeting the Needs of Children and Youth, 25 Soc. SERv. Rev. 156, 158-59 (1951). See also Crystal, What Kecps Us from Giving Children What We Know They Need, 27 Soc. Serv. Rev. 136 (1953); Osborn, Aid to Dependent Chitdren-Realities and Possibilities, 28 Soc. Serv. Rev. 153 (1954); Clothier, Need of New 
financial, and social standards are difficult to locate. ${ }^{2 \pi}$ Private agencies, largely sectarian, limit their admissions to children they consider desirable."s State institutions, which must accept all whom the courts and departments of welfare send, are seriously over-crowded.29 Y' ${ }^{2}$ et some private agencies tend to lse jealous of encroachments upon their respective shares of existing facilities and resist public agency expansion. ${ }^{30}$

Arbitrary religious requirements compound these problems. Children are often denied the special attention their individual needs require because the only homes or agencies which can provide the proper care are in the hands of

Facilities for the Care of Disturbed Children, 34 JIENT. Hro. 97 (1950). Nine states supplied information about existing facilities and all reported inadequacics.

Studies in New York have been the most detailed and demonstrate a glaring nced fur more facilities of all kinds; yet New York has a well developed child welfare program compared to many other states. New York Cirizes's Cosnsitres of O:ar He::dred for Chempen and Youth, Chuld Welfare ix New York State, pts. IX and $X$

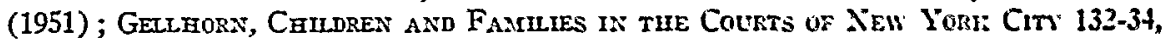
141-48 (1954); KanN, A Court fos Children 119-20, 245, 250-54, 314-15 (1953); Delinquents Jan Youth House, N.Y. Times, Feb. 24, 1955, p. 29, col. 7.

Nevada is all but barren of child welfare facilities. There are no state funds for the direct care of children, only one state institution, no local private institutiuns exceft one private child placing agency, and only one county department of public welfare. The juvenile courts have no funds for child care. Letter from Mrs. Barbara C. Coughlan, State Director, Nevada State Welfare Department, March 17, 1954. Wyoming is in a similar position. The department of public welfare is the only sucial agency in the state and neither the state institutions nor the two private agencies have trained stafis. Letter from Ethylyn Hartwell, Director, Division of Children's Services, Department of Public Welfare, Wyoming, Feb. 25, 1954. Delaware has no state facilities for physically handicapped children. Letter from Mrs. Florence A. Clark, Chief, Child Welfare Services, Delaware, March 2, 1954.

27. "In general, foster-home agencies tend to indict the community for its lack: of generous impulse in opening doors to children who require a family atmosphere . . . Our frustration is inevitable when appeals for foster-homes evoke but little response or when in the response itself we find little that can serve the emotional needs of children." Crystal, What Keeps Us From Giving Children What We know They Nead?, 27 Soc. SEss. Rev. 136 (1953). Thus, children who should be placed in foster homes are often placed in institutions as the only facility available. Letter from Miss Lorena Scherer, State Child Welfare Supervisor, Míssouri, Feb. 24, 1954; KAHN, op. cit. supra note 26, at 119-20, 245, 250-54, 31415; GezlноRл, оp. cit. supra note 26, at 132-34, 141-48. Alabama, California and Missouri conduct a continuous program of foster home recruitment by public education and through civic organizations such as church groups, parent-teachers associations, etc.

28. Seventeen states supplied information concerning the types of private agencies in the state. A majority or substantial portion of such agencies are sectarian. And "the sectarian and private institutions ... control their own intake. They accept only the cases that strike them as suitable and within the limits of their own convenience. . . ." Gellmorn, op. cit. supra note 26, at 133. See also New York State Citizes:s' Cosamttee of One Hundred for Children and Youth, Child Welfare l: New Yums STATE, 95-96, 99 (1951) and KAHN, op. cit. supra note 26, at 251-53.

29. GeLLHONN, op. cit. supra note 26 , at 133 ; $\mathrm{K}$ HzN, op cit. supra note 26 , at $250-51$.

30. KAHN, op. cit. supra note 26 , at 257-58. Confidential communication to the liale Law $J_{\text {ournal }}$ on file in the Yale Law Library. INTERviews. 
persons whose religion differs from that of the child. ${ }^{31}$ And state institutions, non-sectarian by statute, become dumping grounds, since they provide the only facilities available to children without regard to religious considerations. ${ }^{\text {at }}$ Elimination of mandatory religious requirements would allow more effective use of those private homes and agencies which are available for child care and would, at least to some degree, reduce the overtaxing of state facilities. ${ }^{3 a}$

Effect on choice and and efficiency of probation officers. Children's courts usually assign probation officers to neglected and delinquent children on the basis of geography, case load, and special aptitude. ${ }^{34}$ But the New York City Domestic Relations Court requires assignment to a child of the same religion. ${ }^{35}$ And religious groups elsewhere are now pressing for similar requirements. ${ }^{\text {(n) }}$

Assignment of probation officers by religion increases the diffictily of obtaining trained personnel and lowers the overall level of competence. By takings a rough religious census of the children who come before it, the New York Court has established quotas for Catholic, Protestant, and Jewish officers. ${ }^{\text {at }}$ Since vacancies must be filled by persons of the same religion as their prede-

31. INTERvIEWs. While there is need for expansion of all facilities, a recent New York report noted the particular need for institutional facilities of particular religious faiths in upstate New York. New York Cittzens' Commitree of ONe Hundred ron Cintores and Youte, Child Welfare in New York State 99-100 (1951).

Also, in order to meet the needs of all groups in the community, "some modification of the standards is required on occasion for minority groups." Letter from Miss Esther L. Immer, Supervisor of Special Studies, Department of Social IVelfarc, Iowa, April 12, 1954. Thus, the overall level of child care may be lowered to increase facilities of certain groups. The availability of facilities of various denominations is an important item in granting new licenses to institutions and foster homes. Letter from Gerald A. Berlin, Estl., Boston Attorney, March 12, 1954.

32. KAHN, op. cit. supra note 26 , at 251 . INTERviews. Naturally, the effectiveness and reputation of state institutions are seriously damaged. GELLHORN, op. cit. supra note 26 , at 133.

33. Much community effort is needed to improve child care. The elimination of mandatory requirements is a step in that direction. For the great number of problems to be overcome in this field, see the various reports of the Mid-Century White House Conference on Children and Youth, held in 1950. See also Lenroot, Child Wolfart-A Challenge to Private and Public Agencies, 24 Soc. Serv. Rev. 1 (1950).

34. Seven of the eight children's courts reported assignment in this munner.

35. N.Y. Dos. REL. CT. ACT $\$ 25$ states that probation officers shall be assigncd to children of the same faith "when practicable." However, this phrase is overlooked except in boroughs with such small staffs that assignment by religion is practically impossible. KAHN, op. cit. supra note 26, at 142; GeLLHORN, op. cit. supra note 26 , at 118-19. But in the Children's Court of Erie County, which includes Buffalo, "probation workers are never assigned to cases by religious denomination. We expect all of them to be free of bias and to factually report." Letter from Victor B. Wylegala, Judge, Children's Court, Erie County, N.Y., March 3, 1954.

36. There has been a strong movement in Massachusetts for a similar requirement. INTERVIEWS.

37. These quotas are established on the basis of the children appearing before the court rather than on the basis of the religious distribution of the population as a whole. Gelleorn, Children and Families in the Courts of New Yokk City 118-19 (1954). 
cessors, the group from which a given officer may be chosen is substantially limited, and more competent candidates may be excluded from consideration. ${ }^{39}$

Assignment by religion also results in an inefficient use of probation officers. ${ }^{39}$ Since cases then cannot be assigned on a purely geographic basis, officers waste a great amount of time travelling from one probationee to another, and two officers may be working simultaneously in the same block. ${ }^{40}$ This time is extremely valuable to an already overburdened staff." And if officers attempt to save time by arranging to meet probationees at a specified place, usually a school, the semi-institutional setting creates an unnecessarily. formal atmosphere and prevents observation of the child's adjustment to family and home environment. ${ }^{42}$

In those instances where rapport is better when the child and probation officer are of the same religion, individual assignments can be made. There is no need of the inefficiency of mandatory religious assignment to meet this situation. ${ }^{43}$

Effect of compulsory religious conditions of probation. Children's courts encourage religious training for probationees. The majority recommend such programs on an entirely voluntary basis. ${ }^{44}$ But some courts require regular religious observance and education as a condition of probation. ${ }^{45}$

38. The legality of such recruiting practices has been questioned. Simon, Racial and Religious Democracy: Its Effect on Corrcctional Worl, National. Pronatus ann Parole Ass'N Yearbook 205, 205 (1951). Probation officers in New Yorls City are overworked and underpaid. GesLhors, op. cit. supra note 37, at 114-15; Kin:, A Couns For ChILDRen 195-200 (1953). This alone malies the recruiting of competent personnel extremely difficult. With trained candidates in short supply, the broadest possible base for selection would seem a necessity.

39. For a critical analysis of the operation of probation in New York City, sce Kius, op. cit. supra note 38, at 136-223, and GeLLHORN, op. cit. stpra note 37, at 105-24.

40. "The annual loss of staff energy attributable to this one cause reaches a tremendous aggregate" GELLHORN, op. cit. supra note 37, at 300 .

41. Id. at 121-22.

42. See KaHN, op. cit. supra note 38, at 186-87. For the need to obscrve the prob3tioner's environment for successful probation, see Dressler, Prodation asi Parole 46 (1951) ; Anderson, Counselor-Child Relationship, Natronal Probarion and Parole Ass': YEAREOOK 103, 105 (1951).

43. "[I]t is necessary that the assignment be on a geographical basis . . . If more than one officer is working in a particular area, then, of course, we attempt to malie our assignments more personal by taking into consideration racial, religious, and emotional factors." Letter from William B. MrcKesson, Presiding Judge, Juvenile Department, Superior Court, Los Angeles, California, March 11, 1954. "The assignment of probation counselors to cases depends more upon the specific problem presented and the peculiar qualifications of counselors than upon religious faith. However, if there is reason to do so we assign Catholic officers to Catholic children." Letter from Paul IV. Alesander, Judge, Court of Common Pleas, Division of Domestic Relations, Toledo, Ohio, March 6, 1954.

44. Six courts specifically emphasized the point that religious programs for probationers should be entirely voluntary. Two of these courts reported that religious conditions on probation are used by some judges, but the writer opposed such moves in both letters. Two other courts frequently make religious observance and education a condition 
Compulsory religious practice is difficult to justify. Probation is designer to afford advice and guidance in overcoming the problems which resulter in court appearance. 46 Courtroom lectures on religion have little effect on a frightened or belligerent youth. ${ }^{47}$ And religious training, of itself, has a doubtful effect on a delinquent's behavior. ${ }^{48}$ If a religious program appeats advisable, it should be devised by the probation officer in conjunction with the parents and clergy after the officer has had an opportunity to become faniliar with the child's problems. ${ }^{40}$ Judicially imposed religious exercise is seldom warmly accepted, and may actually alienate the child from spiritual values. ${ }^{\text {to }}$

\section{Constitutionality of Mandatory Religious Requirenents}

Mandatory religious requirements appear to be subject to serious constitutional objections based on due process, freedom of religion, and the separation of church and state.

Due process. The subordination of all other factors affecting child welfare to religious considerations would seem to deny children their right to due process

of probation. In Virginia, "religious education and practice, as a condition of prolation, is illegal according to our law." Letter from David H. Katz, Jr., Chief Probation Officer, Juvenile and Domestic Relations Court, Richmond, Virginia, March 11, 1954. Sce Jones v. Commonwealth of Virginia, 185 Va. 335, 38 S.E.2d 444 (1946).

45. "It is the usual requirement of probation that the probationee attend some religions service of his own choosing, or at the direction of his parents, at least once per week while on probation." Letter from Walter H. Beckham, Judge, Juvenilc and Domestic Relations Court, Dade County, Florida, Feb. 26, 1954. Also, some judges of the New York City Domestic Relations Court impose religious conditions on probation. KNuN, op. cit. supra note 38 , at 108 .

46. For a discussion of the aims, methods and requirements of probation, sec Dkessler, Probation and Parole (1951).

47. For extreme instances of ineffective religious lectures by a judgc, see KAnN, op. cit. supra note 38, at 108-12. See also GeLLHORN, op. cit. supra note 37, at 83-84.

48. Many studies have been made on the relationship between religitens instruction and the incidence of delinquency. Several are described and analyzed in Tetaks \& REINEmand, The Challenge of Delinguencr 158-64 (1950); Wattenbcrg, Chutch Attendance and Juvenile Misconduct, 34 Soctoc. and Soctal Researcu 195 (1950). Cf. Harper \& Reinhardt, Four Relationship Status of a Group of Delinquent Boys, 21 J. Cuim. L., C. \& P.S. 379 (1930). See also KaHn, A Court for ChILDren 109 (1953); Gellions, ChIldRex and Families in the Courts of New York City 84 (19\$4), for citations to other research projects on this subject.

49. There must be a readiness on the part of parents to use religious help as well as a relation between the child's problem and religion before any religions program can be effective. See KAHN, op. cit. supra note 47, at 109.

50. "I have seen Orders made requiring the Ward to attend religious cducation classes and church, but $I$ have the feeling that a child who is in attendance at religious services because of the compulsion of a Court Order is not apt to receive benefit as ane who attends a religious service voluntarily, or because of an inward desire." Letter from William B. McKesson, Presiding Judge, Juvenile Department, Superior Court, Lo: Angeles, California, March 11, 1954. See also KAHN, op. cit. supra note 47, at 48. For various approaches which have been taken to make religion a deterrent to juvenile delinquency, see Smith, Role of the Church in Delinquency Prevention, 35 Suciol. ANb Socin. Research 183 (1951). 
of law. Until children reach majority, their own welfare requires the imposition of proper restraints designed to further their best interests. 51 Parental supervision is assumed to accomplish this end. ${ }^{52}$ The state intervenes under its parens patriae power only when the child's welfare is not being adequately served by parental care. ${ }^{53}$ Hence the best interests of the child are at once the source, direction, and limiting consideration in determining the reasonableness of the state's action. ${ }^{54}$ Mandatory religious requirements prevent consideration of the myriad factors which must be weighed if the child is to be placed so as to maximize his welfare. 55 Therefore, state action under such arbitrary requirements deprives the child of his fundamental right to the protection of his best interests. ${ }^{56}$

51. Children are not entitled to the same degree of frcedom as adults. In $r:$ Sharp, 15 Idaho 120, $96 \mathrm{Pac} 563$ (1908). But children do have certain rights, one oî which is that any restraint imposed must protect their welfare. Matter of Thuemmus Guardianship, 233 App. Div. 541, 264 N.Y. Supp. $\$ 29$ (4th Dep't 1933) ; People ex rel. Brown v. Sehifi, 49 N.Y.S.2d 300 (Sup. Ct. 1944). See also Prince v. Mrassachusetts, 321 C.S. 15S, 104 (1944); Commonwealth v. Fisher, 213 Pa. 48, 56, 62 Atl. 198, 201 (1905).

52. Commonwealth v. Fisher, $213 \mathrm{~Pa}$. $48,55,62$ Atl. 198, 201 (1905); ef. F'rince v. Massachusetts, 321 U.S. 158, 166 (1944).

53. Purinton v. Jamrock, 195 Xiass. 187, S0 N.E. $\$ 02$ (1907) ; Mrill v. Brown, 31 Utah 473, \&8 Pac 609 (1907); Milwaukee Industrial School v. Supcrvisors of Mlilwaukse County, 40 Wis. 328 (1876). It is the duty of the state, as parens patriae, to afford such protection to children whose parents are unfit. In re Sharp, 15 Idahy 120, 127, 90 Pac. 563, 565 (1908) (dictum); Commonwealth v. Fisher, 213 Pa. 48, 36-57, 62 Atl. 193, 201 (1905) (same).

54. "He [the court] acts as parens patriac to do what is best for the interests of the child .... He interferes for the protection of infants, qua infants, by virtue of the prerogative which belongs to the Crown as parins patriae." Finlay v. Finlay, 240 X.Y. 429 , 433-34, 148 N.E. 624, 626 (1925). See Guardianship of Walsh, 100 Cal. App. 2d 194, 223 P.2d 322 (1950); In te Guardianship of Waite, 190 Iowa 182, 180 N.1\%. 159 (1920); Matter of Knowack, 158 N.Y. 482, 53 N.E. 676 (1S99); Commonwealth cx rel. Dunie v. Ferree, $175 \mathrm{~Pa}$. Super. 586, 106 A.2d 681 (1954). See also Posserur, Equtry Jumisht:DENCE $\$ \S 1304,1307$ (5th ed. 1941); MLADden, DoMestic Relations $\$ \$ 107-09$ (1931). Thus, if a child's best interests do not determine his custody, the state aets untside its authority. See note 51 supra. Cf. State $e x$ rel. Raymond v. Lawrence, 86 Minn. 310 (1902).

55. See text and footnotes at pp. 776-78 supra under heading Effect on use of scicushisi techniques.

56. In Petitions of Goldman, 121 N.E.2d 843 (Mass. 1954), cerf. denicd, 23 U.S.L. WEEK 3201 (U.S. 1955), the adoption of twins by a family of a different religion was denied. However, it was found that couples of the same religiun, as well suited as the petitioners, were desirous of adopting the twins. Thus, the court may not have felt that the best interests of the children were endangered

While the power of the state to intervene in the custody of children is bascd on its status as parens patriae, state regulation of children's activities while in the homes of their natural parents is based on the police power. Thus, the state can regulate child labor, Sturges \& Burn Mfg. Co. v. Beauchamp, 231 U.S. 320 (1913), and require children at attend school, State v. Bailey, 157 Ind. 324, 61 N.E. 730 (1601). Even if state cuntrol of the custody of children were based on its police power, mandatory religisus requirements would seem to violate the Fourteenth Amendment. The exercise of the police fowcr must have a reasonable relation to ends which are the legitimate objects of legislative actiun. 
Parental exercise of religion. The freedom of religion which is guaranteed by the First Amendment ${ }^{57}$ includes the right of fit parents to control the religious training of their children. 58 This includes the right to change the child's religion if the parents so choose. ${ }^{50}$ One way of changing the religious affiliations of a child is to place it with persons of a different faith. Since mandatory religious requirements prevent parents from doing this, their right to control their children's religious development is impaired..$^{00}$

Separation of church and state. Mandatory religious requirements also appear to violate constitutional prohibitions on the establishment of religion. Onc of the main purposes of the First Amendment was to prevent the imposition of religious status by political authority. ${ }^{\circ 1}$ Yet, where a parent consents to adoption by persons of a different religion,judicial denial based upon mandatory requirements amounts to establishment of the child's religion in disregard of parental wishes. ${ }^{62}$ And the resulting restriction upon the choice of available

Meyer v. Nebraska, 262 U.S. $390,399-400$ (1923). A mandatory requirement would act as an irrebuttable presumption and preclude courts from determining the wclfare of the child. "A statute creating a presumption that is arbitrary or that operates to deny a fair opportunity to repel it violates the due process clause of the Fourteenth Amendment. ... Mere legislative fiat may not take the place of fact in the determination of issttes involving life, liberty or property." Manley v. Georgia, 279 U.S. 1, 6 (1929).

57. U.S. Const. amend. I, which is applicable to the states. Illinois $\mathrm{cx} \mathrm{rcl}$. MicCollum v. Board of Education, 333 U.S. 203 (1948); Kedroff v. St. Nicholas Cathedral, 344 U.S. 94 (1952).

58. West Virginia Board of Education v. Barnette, 319 U.S. 624 (1943): Picrce v. Society of Sisters, 268 U.S. 510, 534-35 (1925) ; Prince v. Massachusetts, 321 U.S. 158, 166 (1944) (dictum). But, neither rights of religion nor of parenthood are beyond limitation if the state acts in a reasonable manner. Ibid.

59. People ex rel. Portnoy v. Strasser, 303 N.Y. 539, 104 N.E.2d 895 (1952). (\%. People ex rel. Sisson v. Sisson, 271 N.Y. 285, 2 N.E.2d 660 (1936). Parents may not be able to change a child's religion where serious emotional harm would result. Matter of Glavas, 203 Misc. 590, 597, 121 N.Y.S.2d 12, 17 (N.Y. Dom. Rel. Ct. 1953) (dictum).

60. This conclusion is not precluded by Petitions of Goldman, 121 N.E.2d 843 (1954), cert. denied, 23 U.S.L. WEEK 3201 (U.S. 1955). The Massachusetts court specifically declined to decide whether placement in the same religion would be "practicable" if the natural mother, rather than merely consenting to adoption by petitioncrs, refused to give the children to any couple but the petitioners.

61. Everson v. Board of Education, 330 U.S. 1, 8-16 (1947). See also 2 ThE Writings OF JEFFERSON 92-103 (1893).

62. In Petitions of Goldman, 121 N.E.2d 843 (1954), cert. denicd, 23 U.S.L. WeEK 3201 (U.S. 1955), the court found children to be of a certain religion because their mother was of that religion. However, the children were not baptized and the mother had consented to their being raised in a different faith. Therefore, the court was under no compulsion to find the children to be members of any religion, and should have restricted itself to deciding whether the adoption was for the children's best interests.

Matter of Santos, 278 App. Div. 373, 105 N.Y.S.2d 716 (1st Dep't 1951), appeal dismissed on other grounds, 304 N.Y. 483, 109 N.E.2d 71 (1952), is a more obvious imposition of religion by a court. There, the trial court's determination that the children were Jewish because of four years of intensive Jewish training and that it was for the best interests of the children to remain in a home where "for the first time [thcy] found security and happiness," Transcript of Record, p. 696, Matter of Santos, 304 N.Y. 483 
custodians impresses temporal consequences on the child due to his religion of birth. ${ }^{63}$

Even where parents are unfit to make decisions affecting their children's welfare, decisions based solely upon religion of birth seem to exceed the state's constitutional authority. For, since all religions are equal before the law, courts lack the power as well as the ability to decide that one will serve a child's spiritual needs better than another. ${ }^{\text {ct }}$ Nor may religious requirements be justified on the ground that they protect "parental rights." Os Once parental unfitness invokes state intervention, the child's welfare takes precedence over parental prerogatives. ${ }^{66}$

Enforcement of religious observance and education as a condition of probation seems patently unconstitutional. ${ }^{67}$ No arm of government may corapel

(1952), was reversed. The mother was unit to care for the children, and, thus, their best interests should have been determinative. But the appellate cuurt found the children to be Catholics because of their baptism (without the father's consent, id. at 697) and their mother's religion, and temporal consequences flowed from that decicion; the children were removed from a fine adoptive home and placed under institutional care. For discussiun of this case, see notes 10 and 20 supra. The rationale of the appellate division is by no means final since the appeal was dismissed by the Court of Appeals on technical grounds and the case was not appeaied after the remand. For a criticism of placing su much emphasis on baptism, see Note, 65 Harv. L. Rev. 694 (1952). See also, Prefres, Cuurcu, State and Freedoar 58S-91 (1953).

Those Supreme Court cases which have upheld state action against a claim of aid to religion did not involve the issues present here. Relcased time from school, Zurach v. Clauson, 343 U.S. 306 (1952), but sie Illinois ex ril. MeCullum v: Board of Education, 333 U.S. 203 (1948), and Note, 61 Y.ALE L.J. 405 (1952), and state transportation for students of parochial schools, Everson v. Board of Education, 330 U.S. 1 (1947), do not impose a particular religion upon a child which conflicts with his best interests or the legally recognized rights of his parents.

63. See text and notes at pp. 776-\$2 supra under heading Effect of Koligiums Reousirements on Child Welfare. As a matter of pure logic, it may be argued that the mere consideration of religion as one of many factors governing decisions concerning child care would also result in an unconstitutional imposition of temporal consequences upon the child. However, the released time cases indicate that the question of constitutionality or unconstitutionality in this area is a matter of degree. Zorach v. Clauson, 343 U.S. 306 (1952), noted in 61 Y ALE I.J. 405 (1952); Illinois cx rel. MicCollum v. Board of Education, 333 U.S. 1 (1947). Thus, the Supreme Court would be more likely to strike duwn a prucedure which has a present detrimental effect upon the child than one winich merely talies religion into account in a manuer not inconsistent with the clild's liest iriterests.

64. Desribes v. Wilmer, 69 Ala. 25 (1831); State ex rol. Baler v. Bird, 253 Mo. 569 , 162 S.W. 119 (1913); Purinton v. Jamrccl, 195 Mass. 1S7, SU N.E. SQ2 (19U7); In re Waite, 190 Iowa 182, 180 N.W. 159 (1920). For a different opinion, see 32 H.U.L. Ra: 448 (1952).

65. For an analysis and collection of cases dealing with parental rights as a detcrminant of a child's religion after placement, see Nute, Rcligion as a Factor in Adoption, Guardianship and Custody, 54 CoLusr. L. Rev. 376 (1954).

66. In re Clough, 28 Ariz. 204, 236 Pac. 700 (1925); Guardianship of IValsh, 100 Cal. App. 2d 194, 223 P.2d 322 (1950) : Purinton v. Jamrock, 195 3Iass. 187, \&0 X.E. Sit? (1907).

67. Jones v. Commonwealth of Virginia, 185 Va. 335, 38 S.E.2d 444 (1946). Mlthough a privilege and not a right, probation cannot be conditioned unconstitutionally. Fleenor 
either attendance at any church or belief in any religion. ${ }^{68}$ And since the constitutional prohibition bars aid to religion as such, as well as to any particular denomination, the fact that all religions benefit equally is irrelevant. ${ }^{60}$

\section{Conclusion}

Mandatory religious requirements, whether statutory or administrative, seriously impede the administration of child welfare programs. They impair effective utilization of existing facilities and techniques for child care, curtail the effectiveness of probation programs, and are open to serious constitutional objections. Religion should be viewed as one of many interfelated factors which must be considered in determining how to promote the child's welfare. Only in this way can the child's best interests be safeguarded in a manner compatible with the constitutional rights of all parties involved. ${ }^{70}$

v. Hammond, 116 F.2d 982 (6th Cir. 1941) ; United States $c . x$ rel. Howard v. Ragen, 59 F. Supp. 374 (N.D. Ill. 1945). See, also, Terral v. Burke Construction Co., 257 U.S. 529 (1922) ; People ex rel. Bernat v. Bicek, 405 Ill. 510, 91 N.E.2d 588 (1950).

68. West Virginia State Board of Education v. Barnette, 319 U.S. 624 (1943); Illinois ex rel. McCollum v. Board of Education, 333 U.S. 203 (1948); Everson v. Boatd of Education, 330 U.S. 1 (1947) ; cf. Zorach v. Clauson, 343 U.S. 306 (1952), Note, 61 YALE L.J. 405 (1952).

69. "Neither [state or federal governments] can pass laws which aid one religion, aid all religions, or prefer one religion over another." Everson v. Board of Education, 330 U.S. 1, 15 (1946).

70. The following quotation from the Indiana Department of Public Welfare Rutles and Regulations is typical of an approach which fulfills the state's obligation to the child without unduly restricting parental preferences or infringing basic constitutional principles: "Each child-placing agency, after giving due consideration to the emotional and physical needs and religious background of the child or parents of the child, shall selcct a foster home or child-caring institution wherein the foster care given to the child will be for the best interests of the child." Indiana Dep't of Public Welfare, Rules and Regulations tit. III, reg. 3-210(d). 